\title{
Pendampingan Belajar dalam Upaya Mengembangkan Kreativitas Belajar Anak pada Masa Pandemi di Desa Buntu Kecamatan Kroya Kabupaten Cilacap
}

\author{
Azharul Kumala*1, Asep Amaludin² \\ 1,2Pendidikan Anak Usia Dini, Fakultas Pendidikan dan Ilmu Keguruan, Institut Agama Islam Negeri \\ Purwokerto, Indonesia \\ *e-mail: azharulkumala.83@gmail.com¹ ${ }^{1}$ asep@iainpurwokerto.ac.id ${ }^{2}$
}

\begin{abstract}
Abstrak
Di masa pandemi seperti saat ini banyak siswa yang kurang memahami atas apa yang disampaikan oleh gurunya karena harus belajar secara online. Selain itu banyak siswa yang menghabiskan waktu mereka hanya dengan bermain handphone atau bermain dengan temannya hingga lupa waktu. Maka dari itu penulis berinisiatif untuk membantu siswa dalam pembelajaran daring dengan melakukan bimbingan belajar dan kelas ketrampilan yang diadakan satu minggu sekali dan tentunya tetap mematuhi protocol kesehatan. Bimbingan belajar dilakukan di Dusun Situmang, Desa Buntu, Kecamatan Kroya, Kabupaten Cilacap, yang sebelumnya telah dibentuk Komunitas Taman Belajar yang bertujuan untuk membantu anak anak dalam pembelajaran dimasa pandemi seperti saat ini. Komunitas ini terdiri dari 3 mahasiswa yang berbeda universitas dan semester, akan tetapi kami sama sama ingin membantu anak anak di desa kami. Pelaksanaan bimbingan belajar kami laksanakan secara tatap muka, dengan berkelompok sesuai pengelompokan kelas. Sedangkan kelas letrampilan kami laksanakan dengan di gabung menjadi satu. Kegiatan ini berlangsung selama KKN DR, dan semoga tetap bisa berlanjut walaupun KKN sudah selesai. Hasil dari kegiatan ini, anak anak maupun orang tua sangat antusias dan bersemangat karena dapat belajar dengan teman-temannya dan mengerjakan tugas secara bersama-sama dan merasa terbantu dengan adanya Komunitas Taman Belajar.
\end{abstract}

Kata kunci: Kreativitas Belajar, Pandemi COVID-19, Pendampingan Belajar

\begin{abstract}
In times of a pandemic like today, many students do not understand what the teacher is saying because they have to study online. In addition, many students spend their time just playing with their cellphones or playing with their friends until they forget the time. Therefore, the author took the initiative to help students in online learning by conducting tutoring and skills classes which were held once a week and of course still complying with the health protocol. Tutoring is carried out in Situmang Hamlet, Buntu Village, Kroya District, Cilacap Regency, where the Learning Garden Community has previously been formed which aims to help children in learning during the current pandemic. This community consists of 3 students from different universities and semesters, but we both want to help the children in our village. The implementation of our tutoring is carried out face-to-face, in groups according to class groupings. Meanwhile, our skill classes are carried out by merging them into one. This activity took place during the DR KKN, and hopefully it can continue even though the KKN is finished. The results of this activity, children and parents are very enthusiastic and excited because they can learn with their friends and do assignments together and feel helped by the existence of the Learning Garden Community.
\end{abstract}

Keywords: COVID-19 Pandemic, Learning Assistance, Learning Creativity

\section{PENDAHULUAN}

Saat ini dunia sedang mendapatkan musibah besar yaitu pandemi COVID-19 atau virus corona. Coronavirus yaitu virus yang menyebabkan penyakit mulai dari gejala ringan sampai dengan berat bahkan kematian. Seluruh dunia saat ini sedang merasakan dampaknya, mulai dari ekonomi, pendidikan, social, pembangunan, dan lain-lain (Nurdin \& Anhusadar, 2020). Dan pada akhirnya pemerintah membuat beberapa kebijakan seperti menghentikan kegiatan kontak langsung dengan orang-orang dan kerumunan. Seperti halnya dalam pendidikan, menetapkan kebijakan transformasi kegiatan pembelajaran melalui dalam jaringan (daring). 
Pembelajaran daring dilaksanakan mulai dari tingkat pendidikan PAUD/TK sampai perkuliahan. Untuk kalangan anak usia dini dan anak anak yang bersekolah di sekolah dasar sangat membutuhkan bimbingan orang tua dalam pembelajaran. Dalam jurnal yang saya baca, menurut (Meidawati, 2019) pembelajaran daring merupakan pembelajaran yang memenfaatkan teknologi. Menurut (Rigianti, 2020) pembelajaran daring adalah cara baru dalam pembelajaran dengan memanfaatkan perangkat elektronik berupa gawai atau laptop khususnya pada akses internet dalam penyampaiannya ketika pembelajaran, sehingga pembelajaran daring sepenuhnya bergantung kepada akses jaringan internet. Dengan pembelajaran daring ini siswa memiliki waktu yang lebih leluasa untuk belajar, dapat belajar dimanapun dan kapanpun. Dalam pembelajaran daring, siswa melakukan proses pembelajaran melalui grup whatsapp, video pembelajaran di youtube, google meet, google classroom, zoom, dan telegram (Dewi, 2020). Pembelajaran dapat berjalan baik dan efektif apabila guru kreatif dalam memberikan materi belajar dan latihan soal kepada siswanya sehingga siswa tidak bosan ketika melakukan pembelajaran secara daring.

Dengan adanya pembelajaran daring, berbagai masalah muncul, seperti kurangnya pemahaman siswa dengan materi yang disampaikan oleh gurunya, dan siswa yang menggunakan kesempatan belajar daring dengan hanya bermain game online. Hal ini disebabkan oleh beberapa factor seperti kurangnya kemandirian siswa dalam belajar, tidak siapnya orang tua untuk mendampingi dan membimbing anaknya belajar di rumah. Maka dari itu, orang tua memegang peran penting untuk mengawasi dan memberikan fasilitas kepada anak dalam proses pembelajaran. Akan tetapi, tidak semua orang tua mampu menjadi pengawas dan memberikan fasilitas belajar anak di rumah dengan berbagai alasan, di antaranya yaitu tuntutan pekerjaan yang harus dilakukan baik di luar maupun di dalam rumah, kurangnya pengetahuan dan pengalaman orang tua dalam membantu anaknya untuk memahami materi yang disampaikan oleh gurunya, dan kurangnya kesadaran orang tua untuk membimbing anaknya belajar di rumah. Keadaan ini akan mengakibatkan tujuan pembelajaran yang tidak tercapai secara maksimal.

Berdasarkan permasalahan di atas, penulis berinisiatif untuk membentuk Komunitas Taman Belajar yang nantinya akan membimbing proses pembelajaran anak anak di Dusun Situmang, Desa Buntu, Kecamatan Kroya. Komunitas ini terdiri dari 3 mahasiswa yang berbeda universitas dan semester, akan tetapi kami sama sama ingin membantu anak anak di desa kami. Menurut Juhana Wijaya bimbingan belajar merupakan salah satu kegiatan yang penting. Bimbingan belajar ini menitikberatkan pemberian bantuan pada siswa dalam usahanya mencapai keberhasilan menguasai mata pelajaran dan nilai nilai yang baik sesuai dengan kurikulum sekolah. Menurut (Prayitno, 2004) pengalaman menunjukkan bahwa kegagalan yang dialami siswa dalam belajar tidak semata mata disebabkan oleh kebodohan atau rendahnya intelegensi. Seringkali kegagalan itu terjadi karena mereka tidak mendapatkan bimbingan belajar yang memadai. Dengan demikian dapat diartikan bahwa bimbingan belajar memiliki nilai positif dan manfaat tersendiri bagi anak. Maka dari itu, tujuan diadakannya bimbingan belajar oleh Komunitas Taman Belajar adalah untuk membantu proses pembelajaran siswa siswi SD-SMP dan mengisi waktu luang siswa siswi dengan kelas ketrampilan yang dapat mengembangkan kreativitas siswa siswi di Dusun Situmang, Desa Buntu, Kecamatan Kroya.

\section{METODE}

Metode pelaksanaan kegiatan sebagai berikut:

A. Rancangan Kegiatan

Sebelum melaksanakan bimbingan belajar, berikut rencana kegiatannya:

- Membentuk Komunitas Taman Belajar yang terdiri dari 3 mahasiswa dari kampus yang berbeda dan semester yang berbeda pula. Akan tetapi kami memiliki tujuan yang sama yaitu ingin membantu anak anak disini dalam pembelajaran daring.

- Pembuatan pamflet dan pemasangan pamflet di tempat umum.

- Mengajak anak anak Dusun Situmang mengikuti bimbingan belajar secara gratis. 
- Mendatangi wali dari anak yg mengikuti bimbingan belajar dengan tujuan menjelaskan maksud dan tujuan serta jadwal belajar anak.

- Persiapan perlengkapan penunjang belajar anak.

- Persiapan materi yang akan disampaikan ketika ada kelas ketrampilan yang akan dilaksamakan setiap satu minggu sekali, tepatnya di hari minggu.

B. Lokasi Kegiatan

Untuk bimbingan belajar setiap harinya dilakukan dirumah masing masing pembimbing sesuai jadwal. Tepatnya di Dusun Situmang, RT 02 RW 03 Desa Buntu.

C. Partisipant Kegiatan

Partisipant kegiatan bimbingan belajar yaitu anak SD sampai SMP dusun Situmang yang berjumlah kurang lebih 20 anak dengan 2 anak SMP dan lebihnya SD.

D. Bahan dan alat

Bahan dan alat yang digunakan yaitu papan tulis, buku, dan alat tulis, ini digunakan untuk setiap kali pertemuan. Sedangkan kertas hvs, origami, pewarna makanan, tissue, gunting, dauble tip, krayon, spidol, adalah alat dan bahan yang digunakan ketika kelas ketrampilan.

E. Metode Pelaksanakaan Kegiatan

Metode yang digunakan adalah metode pembelajaran luring atau tatap muka dengan tetap mematuhi protocol kesehatan. Dengan tidak berkerumun, tetap memakai masker dan mencuci tangan sebelum pembelajaran.

F. Metode Pengumpulan Data

Data dikumpulkan dengan observasi dan wawancara. Dimana observasi adalah pengumpulan data dengan penulis melakukan pengamatan langsung tentang bagaimana pembelajaran daring di saat pandemic ini dan wawancara adalah pengumpulan data yang dilakukan dengan cara berdialog dengan anak anak dan wali dari anak anak.

G. Hasil Kegiatan

Setelah terlaksananya kegiatan bimbingan belajar di Dusun Situmang, Desa Buntu, Kecamatan Kroya, anak anak maupun orang tua sangat antusias dan bersemangat karena dapat belajar dengan teman-temannya dan mengerjakan tugas secara bersama-sama. Dan merasa terbantu dengan adanya Komunitas Taman Belajar.

\section{HASIL DAN PEMBAHASAN}

\subsection{Pandemi COVID-19}

Corronavirus merupakan keluarga besar dari virus yang meyebabkan penyakit, mulai dari ringan sampai berat. Ada setidaknya dua jenis coronavirus yang diketahui menyebabkan penyakit yang dapat menimbulkan gejala berat seperti Middle East Respiratory Syndrome (MERS) dan Severe Acute Respiratory Syndrome (SARS), dan yang terbaru varian delta yang dapat mematikan. COVID-19 adalah penyakit yang belum pernah diidentifikasi sebelumnya pada manusia. Tanda dan gejala umumnya antara lain seperti demam, baruk, dan sesak napas. Masa inklubasi rata-rata 5-6 hari dengan masa inklubasi terpanjang 14 hari (Yurianto, Ahmad, \& Wibowo, 2020).

Pandemi COVID-19 membawa pengaruh terhadap semua bidang kehidupan, khusunya dalam bisang pendidikan. Akibat dari pandemic COVID-19, pelaksanaan sekolah dari taman kanak-kanak hingga universitas di tutup. UNESCO mengatakan bahwa 300 juta murid terganggu kegiatan sekolahnya dan penutupan sekolah sementara akibat dari kesehatan dan krisis (Handoyo, 2020). Akibat dari pandemic ini, menyebabkan diterapkannya berbagai kebijakan untuk memutus rantai penyebaran virus COVID-19 di Indonesia. Upaya yang dilakukan oleh pemerintah salah satunya dengan menerapkan kepada masyarakat untuk menghindari kerumunan. Upaya tersebut ditujukan kepada masyarakat agar dapat dilakukan dengan tujuan untuk memutus rantai penyebaran pandemic COVID-19 (Siahaan, 2020).

Dengan adanya pembatasan interaksi dan perintah menghindari kerumunan, Kementrian Pendidikan di Indonesia mengeluarkan kebijakan meliburkan sekolah dan menggantinya dengan 
kegiatan belajar mengajar secara daring. Dengan sistem pembelajaran daring, muncul berbagai masalah yang dihadapi oleh siswa dan guru. Seperti pembelajaran yang belum selesai disampaikan oleh guru kemudian mengganti dengan tugas lainnya, siswa yang tidak faham dengan materi yang di sampaikan guru, ketika pembelajaran tiba tiba kuota internet habis, sinyal internet yang susah, tidak adanya handphone android dsb (Siahaan, 2020).

\subsection{Pendampingan Belajar}

Pandemi covid 19 mengakibatkan dampak yang besar bagi masyarakat dan dari berbagai bidang salah satunya bidang Pendidikan. Mengakibatkan kegiatan pembelajaran yang awalnya dilakukan tatap muka di sekolah kini harus dilakukan secara daring di rumah masing-masing dengan menyesuaikan kemampuan masing-masiang tiap sekolah. Hal tersebut menjadikan banyak permasalah muncul. Seperti anak tidak dapat mengikuti pembelajaran karena tidak ada kuota internet, dan parahnya lagi orang tua yang tidak memiliki handphone android untuk dapat mengikuti pembelajaran daring.

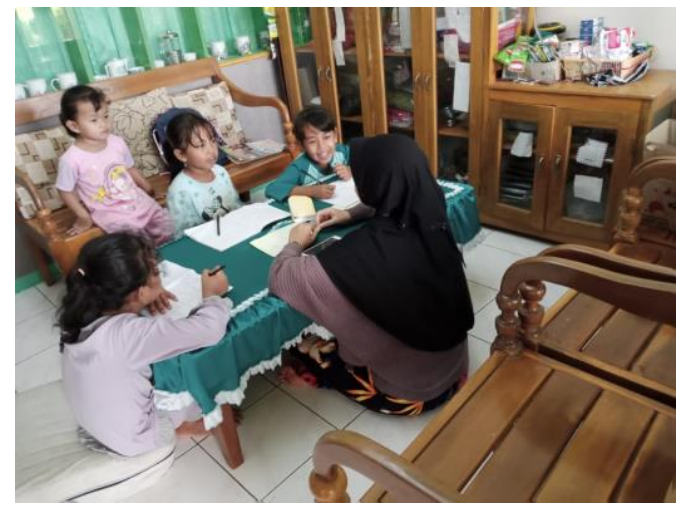

Gambar 1. Diskusi dengan anak perihal pembelajaran daring

Menurut Juhana Wijaya bimbingan belajar merupakan salah satu kegiatan yang penting. Dalam jurnal (El \& Purbaya, 2016), bimbingan belajar adalah bimbingan dalam hal menemukan cara belajar yang tepat, dalam memilih program studi yang sesuai, dan dalam mengatasi kesukaran-kesukaran yang timbul berkaitan dengan tuntunan-tuntunan belajar di suatu institusi pendidikan. Bimbingan belajar ini menitikberatkan pemberian bantuan pada siswa dalam usahanya mencapai keberhasilan menguasai mata pelajaran dan nilai nilai yang baik sesuai dengan kurikulum sekolah. Dalam proses bimbingan belajar, diperlukan kerja sama antara guru dan orang tua agar dapat memastikan adanya interaksi dan kegiatan belajar anak dengan baik.

Program belajar dari rumah dilakukan secara mandiri dirumah masing masing. Selama pembelajaran dari rumah banyak anak yang mengeluh kesulitan mengikuti pembelajaran. Contohnya anak merasa bosan, salah satu penyebabnya karena guru menyampaikan materi tidak dijelaskan secara detail. Hanya mengirimkan foto bahkan langsung diberi tugas.

Adanya kendala tersebut juga berdampak bagi orang tua. Seperti orang tua yang bekerja dan orang tua yang tidak mengenyam pendidikan tinggi. Orang tua yang bekerja merasa kesulitan membagi waktu antara bekerja dan membantu anak belajar dari rumah. Sedangkan orang tua yang tidak mengenyam pendidikan tinggi merasa kesulitan dalam membantu anak belajar karena keterbatasan pengetahuan mereka terhadap materi belajar anak saat ini. Saat saya melakukan wawancara kepada orang tua, beberapa orang tua mengeluh karena tidak faham dengan materi belajar anak, orang tua juga merasa terbebani karena harus mengerjakan tugas anak akibat anak yang tidak faham dengan materi yang disampaikan guru secara daring. Hal tersebut terkadang membuat orang tua kesal, karena sudah lelah bekerja atau mengurus rumah tangga, harus ditambah lagi dengan mengerjakan tugas anak. Tidak jarang orang tua yang akhirnya emosi saat membantu anak mengerjakan tugasnya. Maka dari itu, anak tidak nyaman belajar dari rumah bersama orang tuanya. 
Selain berdampak bagi anak dan orang tua, pembelajaran daring juga berdampak bagi guru. Guru menjadi tidak leluasa dalam menyampaikan materi belajar, tidak dapat melihat perkembangan anak secara langsung, tidak dapat melihat kemajuan atau prospek belajar anak, dan penilaian pun hanya dilihat dari tugas dan absensi (Rita \& Azzahra, 2020). Ditambah lagi dengan kemampuan IT setiap guru berbeda. Saya melihat di lingkungan saya masih jarang guru TK, dan SD terutama yang mahir dalam hal teknologi. Maka dari itu terkadang materi yang disampaikan guru monoton, dan kurang menarik.

Dalam kegiatan KKN DR saat ini, saya berinisiatif membuat program bimbingan belajar karena saya pikir ini akan dapat membantu anak anak dan orang tua di desa saya. Bimbingan belajar saya lakukan di Dusun Situmang, Desa Buntu, Kecamatan Kroya, Kabupaten Cilacap. Sebelum saya membuat program bimbingan belajar ini, saya membentuk Komunitas Taman Belajar yang terdiri dari 2 mahasiswa dari kampus berbeda dan semester yang berbeda pula, akan tetapi kami memiliki tujuan sama yaitu membantu anak anak di Dusun Situmang dalam belajar secara daring.

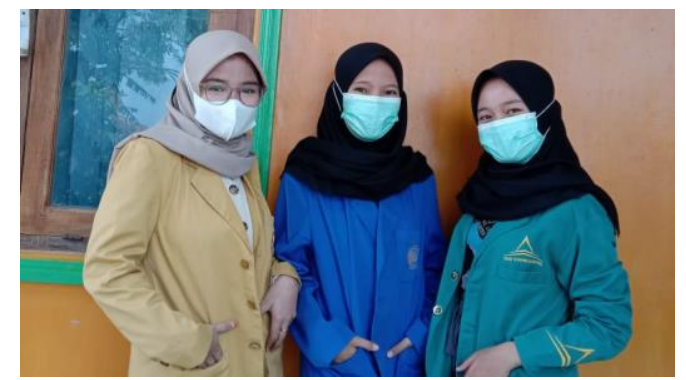

Gambar 2. Relawan Komunitas Taman Belajar

Dalam program bimbingan belajar ini terdapat 2 kegiatan. Yang pertama kegiatan bimbingan belajar yang dilakukan setiap hari senin-jumat dengan waktu fleksibel, dan kegiatan kelas ketrampilan yang dilakuakan satu kali dalam satu minggu yaitu hari minggu jam 10.0013.00. Anak anak yang mengikuti bimbingan belajar mulai dari tingkat SD sampai SMP. Sedangkan untuk kelas ketrampilan sasarannya adalah anak anak TK dan SD.

Bimbingan belajar yang saya lakukan dengan teman teman adalah mata pelajaran umum. Jika anak ada PR atau tugas dari guru, maka saya membimbing anak untuk menyelesaikan tugastugasnya, sedangkan jika anak tidak ada PR atau tugas dari gurunya, maka saya akan memberikan materi terkait materi yang anak belum begitu kuasai atau materi untuk keesokan harinya. Durasi waktu yang kami gunakan untuk belajar adalah 1 jam. Kecuali untuk anak SMP, kami menambah waktu 20 menit, sehingga menjadi 80 menit. Pembelajaran yang saya lakukan yaitu dengan belajar sambil bermain. Misalkan untuk anak tingkat SD kelass 1 ketika akan belajar matematika, saya mengajarkan dengan memberikan dia buku hitungan sederhana dengan dilengkapi gambar yang membuat anak lebih tertarik untuk menghitung, atau dengan menghitung benda benda disekitar.

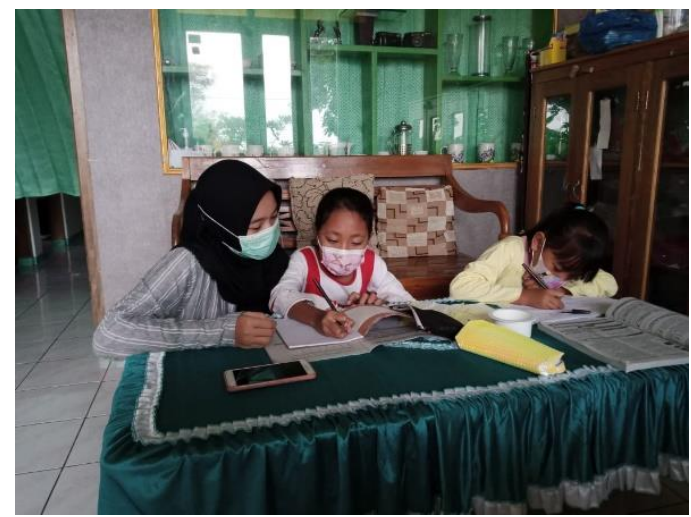

Gambar 3. Bimbingan belajar kelas 3 dan 4 SD 
Hasil dari program bimbingan belajar yang Komunitas Taman Belajar adakan, orang tua sangat antusias dengan program bimbingan belajar ini. Orang tua merasa terbantu, karena tidak harus susah susah mengerjakan tugas anak lagi. Begitupun dengan anak anak, mereka sangat antusias dan bersemangat untuk mengikuti kegiatan kegiatan yang saya dan teman teman adakan. Menurut mereka, dengan bimbingan belajar ini, mereka merasa terbantu, terutama saat ada tugas dari guru dengan materi yang menurutnya susah untuk dikerjakan sendiri. Mereka juga semangat belajar karena belajar bersama teman temannya, bisa saling bantu dan bercengkrama ke sana sini, mereka merasa bimbingan belajar tetap berjalan baik walaupun dengan pembelajaran yang santai.

\subsection{Kreativitas Belajar}

Dalam jurnal yang saya baca, banyak pendapat para ahli menjelaskan tentang pengertian kreativitas. Menurut (Semiawan, 2010) menjelaskan bahwa kreativitas adalah kemampuan menghasilkan bentuk baru dalam seni atau dalam permesinan atau dalam memecahkan masalah masalah dengan metode-metode baru. (Rachmawati, 2010), mengatakan bahwa Kreativitas adalah kemampuan seseorang untuk melahirkan sesuatu yang baru, baik berupa gagasan maupun karya yang nyata yang relative berbeda dengan apa yang telah ada. Menurut Mayesky kreativitas adalah cara berfikir dan berbuat sesuatu sesuai gayanya dan berbeda pada setiap orang (Mayesky, 1990). Kreativitas adalah cara seseorang untuk berfikir dan berbuat yang berbeda dan sesuai dengan caranya sendiri. Dapat disimpulkan bahwa kreativitas adalah kemampuan yang dimiliki seseorang untuk menemukan dan menciptakan hal baru, cara baru, atau model baru yang kelak berguna bagi dirinya atau masyarakat. Sedangkan kreativitas belajar menurut Martini adalah kemampuan siswa untuk menemukan cara-cara yang baru dalam rangka menyelesaikan masalahmasalah yang berhubungan dengan pembelajaran. Setelah saya simpulkan, kreativitas belajar adalah kemampuan untuk menemukan cara memecahkan permasalahan yang dihadapi dalam pembelajaran yang didasarkan pada tingkah laku seseorang.

Saat ini tidak hanya orang tua yang dituntut untuk berfikir kreatif, gurupun harus mampu untuk menyampaikan materi kepada siswanya, bagaimana agar pembelajaran tidak membosankan, bagaimana guru dapat mengembangkan media pembelajaran yang sesuai dengan kondisi siswanya dan gurupun harus mampu untuk memotivasi agar siswa dapar bersemangat dalam mengikuti pembelajaran dari rumah (Rizkiyyah, dkk, 2021).

Dalam jurnal yang saya baca, ada empat hal yang dapat diperhitungkan dalam pengembangan kreativitas, sebagai berikut:

1. Memberikan rangsangan mental, baik pada aspek kognitif maupun kepribadiannya serta suasana psikologis.

2. Menciptakan lingkungan kondusif yang memudahkan anak untuk mengakses apapun yang dilihatnya, dipegangnya, didengarnya, dan dimainkannya.

3. Peran serta guru dalam mengembangkan kreativitas.

4. Peran serta orang tua dalam me-ngembangkan kreativitas anak.

Program bimbingan belajar yang saya adakan bersama teman teman, selain membimbing anak belajar, setiap satu minggu sekali ada kegiatan kelas ketrampilan. Biasanya kegiatan ini dilaksanakan di hari Minggu, jam 10 sampai jam 1 siang. Kegiatan ini diikuti oleh anak anak yang mengikuti bimbingan belajar dan anak anak lain yang tidak mengikuti bimbingan belajar, Jadi kelas ketrampilan ini sifatnya umum, siapa saja boleh ikut. 

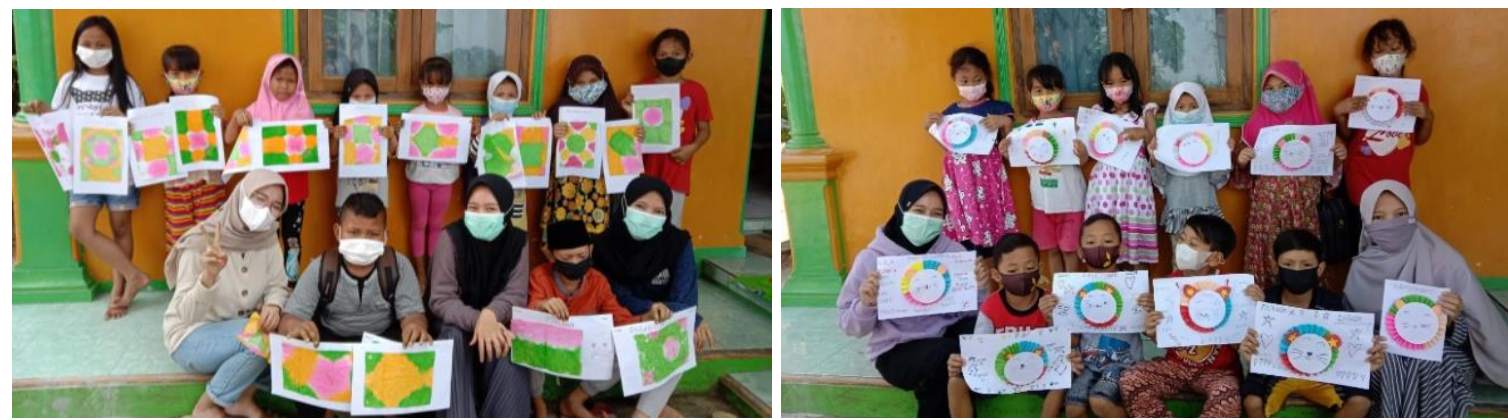

Gambar 4. Kegiatan Kelas Ketrampilan

Dalam kegiatan ini saya dan teman teman mengajarkan sesuatu yang dapat mengembangkan kreativitas anak. Contohnya, kegiatan menjumput dengan tisu, melukis dengan pewarna makanan, membuat mahkota, membuat mainan kipas kipasan, dan membuat mainan anak. Selain itu, beberapa pembelajaran saat bimbingan belajar sering menggunakan metode bermain sambil belajar yang dapat mengembangkan kreativitas belajar anak juga. Misalnya, ada 1 anak bimbingan saya yang saya sebut dengan "anak special" atau berkebutuhan khusus sehingga perlu ekstra sabar ketika pembelajaran. Maka dari itu saya menggunakan metode belajar sambil bermain, agar anak enjoy dan tidak mudah bosan. Bisa dengan membentuk huruf ABCD dengan lilin mainan, atau dengan menggunakan mainan huruf yang menarik minat anak.

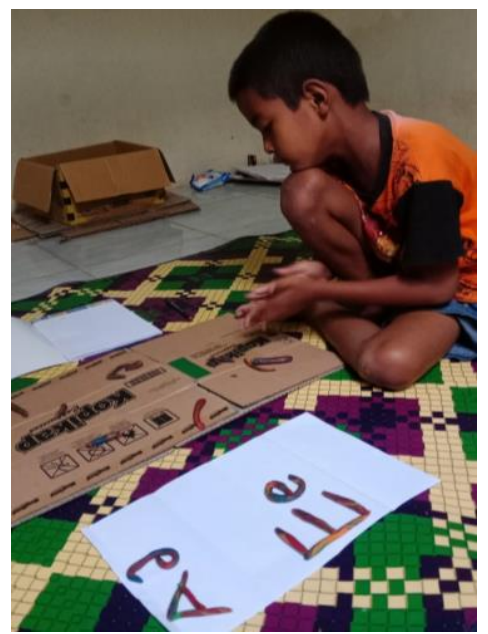

Gambar 5. Bimbingan Belajar kelas 1 SD

Dalam kegiatan ini anak anak sangat antusias dan bersemangat. Orang tua pun mendukung kegiatan ini, karena setidaknya, hari libur anak dapat digunakan dengan hal yang bermanfaat, dan tidak hanya bermain bersama teman temannya ataupun menghabiskan hari libur dengan bermain handphone dan menonton TV saja.

\section{KESIMPULAN}

Pembelajaran daring selama pandemic berjalan kurang efektif. Selain itu, banyak kendalakendala yang muncul saat pembelajaran daring berlangsung baik dari masalah teknis maupun proses pembelajaran itu sendiri.

Pendampingan belajar dilakukan di Dusun Situmang, Desa Buntu, Kecamatan Kroya Kabupaten Cilacap dinilai sangat membantu dalam pembelajaran daring. Dapat dilihat dengan antusias anak anak maupun orang tuanya. Anak anak merasa terbantu karena ada yang membimbingnya ketika belajar online, anak anak juga merasa senang karena memiliki pengalaman baru ketika ada kelas ketrampilan. Begitupun dengan orang tua yang merasa terbantu karena adanya Kominitas Belajar ini. Terutama untuk orang tua yang bekerja dan yang 
tidak mengenyam pendidikan tinggi. Maka dari itu orang tua sangat antusias dengan diadakannya pendempingan belajar dan kelas ketrampilan

\section{UCAPAN TERIMA KASIH}

Ucapan terima kasih saya sampaikan kepada Bapak Rustam selaku kepala Desa Buntu, Kecamatan Kroya, yang telah mendukung terlaksananya penelitian ini. Saya ucapkan terima kasih kepada Bapak Asep Amaludin selaku Dosen Pembimbing Lapangan yang telah membimbing saya dan kawan-kawan. Tidak lupa saya ucapkan terima kasih juga kepada anak anak dan orang tua karena telah berkenan memberi data yang sangat berarti untuk penelitian ini dan berkenan untuk ikut serta dalam kegiatan bimbingan belajar

\section{DAFTAR PUSTAKA}

Amti, Erman, dan Prayitno. (2004). "Layanan Bimbingan Dan Konseling Kelompok". Padang: Jurusan Bimbingan Dan Konseling Fakultas Ilmu Pendidikan Universitas Negeri Padang.

Dewi, W.A.F. (2020). "Dampak COVID-19 Terhadap Implementasi Pembelajaran Daring Di Sekolah Dasar". Jurnal Ilmu Pendidikan. Vol 2 No. 1

El, F.R. \& Purbaya, A.P. (2016). "Penerapan Bimbingan Belajar dalam Meningkatkan Hasil Belajar Peserta Didik di SMP Negeri 12 Kota Bandar Lampung Tahun Pelajaran 2015/2016". Jurnal Bimbingan dan Konseling. Vol 03. No 2

Handayani, T., dkk. "Pendampingan Belajar Di Rumah Bagi Siswa Sekolah Dasar Terdampak COVID19". Jurnal Pengabdian Masyarakat. Vol. 1 No. 1

Handoyo. (2020). Wabah virus corona ancam 300 juta siswa. Kontan.Co.Id.

Manobe, S.M. \& Wardani, K.W. "Peningkatan Kreativitas Belajar IPA Menggunakan Model Problem Based Learning Pada Siswa Kelas 3 SD". Vol. 6 No. 8

Nurdin, N., \& Anhusadar, L. (2020). "Efektivitas Pembelajaran Online Pendidik PAUD di Tengah Pandemi COVID-19". Jurnal Obsesi: Jurnal Pendidikan Anak Usia Dini, Vol. 5 No. 1

Rachmawati. (2010). "Strategi Pengembangan Kreativitas Pada Anak Usia Taman Kanak-Kanak". Jakarta: Kencana Prenada Media Group.

Rizkiyah, dkk. (2021). "Upaya Meningkatkan Kualitas Dan Kreativitas Belajar Melalui Program Bimbingan Belajar Di Masa Pandemi COVID-19”. Jurnal Pengabdian Masyarakat. Vol. 3 No.1.

Semiawan. (2010). "Kreativitas dan Keberbakatan". Jakarta: PT. Indeks

Siahaan \& Matdio. (2020). "Dampak Pandemi COVID-19 Terhadap Dunia Pendidikan". Jurnal Kajian Ilmiah

Yurianto, Ahmad, \& Wibowo, K.P.B. (2020). "Pedoman PEncegahan Dan Pengendalian Coronavirus Diseasea (COVID-19)" (M. I. Listiana Azizah, Adistikah Aqmarina (ed.) 